\title{
AUTOMATED WASTE COLLECTION CONTAINER LID OPENER PROTOTYPE AND DISINFECTANT SPRAYER AS PART OF NOSOCOMIAL INFECTION PREVENTION
}

\author{
Fatahah Dwi Ridhani ${ }^{1)}$ \\ ${ }^{1}$ Jurusan Teknik Elektromedik, Politeknik Kesehatan Kementerian Kesehatan Jakarta \\ II, Kebayoran Baru, Jakarta Selatan, 12120 \\ E-mail: ridhani@poltekkesjkt2.ac.id ${ }^{1)}$ \\ Submitted: $25^{\text {th }}$ June 2021; Accepted: $15^{\text {th }}$ July 2021 \\ https://doi.org/10.36525/sanitas.2021.1
}

\begin{abstract}
Nosocomial infection is a health issues related to the in-hospital activities. One of the indirect cause was the contamination related to the waste disposal activity. All hospital waste was deemed hazardous that it needs extra care during collection. Cross contamination may arises when the waste containers was not treated. To alleviate the problem and to promote healthy habits, this article describe a smart disinfectant sprayed waste collection container and its status reports. By automating the lid opening and closing that was triggered by human proximities using passive infrared detector and ultrasound sensor, it provide convenience in waste disposal. This also prevent cross contamination related with physical contact with the waste container which may induce the nosocomial infection. The container also tracking its remained waste capacity and will report when it was almost full to prevent overflowed and to alarmed for immediate waste pickup. In case of delayed container collection, the lids will remain closed and the light indicator turn to red. The indicator will turn green in normal conditions and turn yellow if the container was almost full. ESP32 was used to interface with ultrasound sensors to approximate the container remaining capacity. Passive infrared sensor and a servo motor was linked to actuates the lid opening and closing. Some disinfectant was sprayed for every detected increase in waste level. The disinfectant aerosol canister was pushed by a DC motor. For reporting, the systems was equipped with LoRa for status report. This systems was tested inside Poltekkes Kemenkes Jakarta II building and could reach at least $80 \mathrm{~m}$ distance from the report center for reporting.
\end{abstract}

Keywords: Nosocomial infection prevention, disinfectant sprayed waste container, LoRa.

This is an open access journal, and articles are distributed under the terms of the Creative Commons Attribution-Non Commercial-Share Alike 4.0 License, which allows others to remix, tweak, and build upon the work non-commercially, as long as appropriate credit is given and the new creations are licensed under the identical terms. C2021 Sanitas 


\title{
PURWARUPA OTOMATISASI PEMBUKAAN TUTUP TEMPAT SAMPAH DAN PENYEMPROTAN DISINFEKTAN SEBAGAI BAGIAN PENCEGAHAN INFEKSI NOSOKOMIAL
}

\begin{abstract}
ABSTRAK
Infeksi nosokomial adalah masalah kesehatan yang berkaitan dengan kegiatan di rumah sakit. Salah satu penyebab tidak langsungnya adalah dalam aktivitas pembuangan limbah. Untuk mengatasi masalah dan mempromosikan kebiasaan sehat, artikel ini menjelaskan tentang pengendalian tempat sampah pintar dan pelaporan statusnya. Dengan mengotomatiskan pembukaan dan penutupan tutup yang dipicu oleh perkiraan keberadaan manusia menggunakan detektor inframerah pasif, memberikan kemudahan dalam pembuangan limbah. Ini juga untuk mencegah kontaminasi silang dari kontak fisik yang dapat menyebabkan infeksi nosokomial. Wadah tersebut juga melacak kapasitas limbah yang tersisa dan akan melaporkan kapan hampir penuh untuk mencegah meluap dan memperingatkan untuk pengambilan limbah segera. Dalam hal pengumpulan kontainer yang tertunda, tutupwadah akan tetap tertutup dan indikator lampu berubah menjadi merah. Indikator akan berubah hijau dalam kondisi normal dan menguning jika wadah hampir penuh. ESP32 digunakan untuk berinteraksi dengan sensor ultrasonik untuk memperkirakan kapasitas sisa wadah. Sensor inframerah pasif dan motor servo mini dihubungkan untuk mengaktifkan pembukaan tutupnya. Selama wadah masih bisa menerima sampah, ketika menutup maka akan diperiksa ketinggian sampah dan disemprotkan sedikit desinfektan aerosol yang diaktifkan oleh motor DC. Sistem dilengkapi dengan LoRa untuk melaporkan status sistem. Alat ini diuji di dalam bangunan gedung kuliah Poltekkes Jakarta 2 dan didapatkan jarak komunikasi terjauh dengan pusat pengawasan sekitar $80 \mathrm{~m}$.
\end{abstract}

Kata Kunci: Pencegahan infeksi nosokomial, tempat sampah dengan desinfektan semprot, LoRa

\section{PENDAHULUAN}

Infeksi nosokomial adalah resiko kesehatan yang terjadi pada interaksi pasien, tenaga kesehatan dan pihak lainnya yang berada di lingkup tempat pelayanan kesehatan atau dikenal dengan istilah Health-care Associated Infection (HAIs). Faktorfaktor yang memungkinkan terjadinya infeksi nosokomial beberapa dijelaskan oleh (1) dan (2), salah satunya terkait limbah dan kontaminasi silang. Tenaga nakes yang telah memahami pentingnya konsep pencegahan infeksi nosokomial dan telah mendapatkan pelatihan pun tidak luput dari ketelodoran, semisal yang dilaporkan oleh (3) dan (4) bahkan sampai adanya keberatan dalam pengaturan penempatan limbah medis dalam wadah bertanda khusus. Pentingnya pengendalian perilaku non pasien dan nakes juga mendukung dalam pencegahan infeksi nosokomial (5), (6) dan (7). Tercatat juga hewan yang menjadi penghuni tempat sampah menjadi vektor penyebab infeksi nosokomial (8).

Perangkat sederhana dengan berbasis kontrol mikrokontroler dipakai dalam banyak alat yang membantu baik langsung atau sebagai penunjang pelayanan kesehatan. Sebagai contoh (9) menyusun alat kesehatan sederhana untuk pengondisian 
pasien. Perangkat lain misalnya (10) memanfaatkan mikrokontroler untuk mengukur kinerja alat kesehatan. Perangkat untuk mengukur kinerja pendukung pelayanan kesehatan juga dikembangkan menggunakan sistem mikrokontroler (11).

Tempat sampah cerdas telah diteliti oleh banyak penulis dengan berbagai variannya, salah satunya (12) yang menggunakan sensor ultrasonik untuk mendeteksi kapasitas juga keberadaan pengguna. Tambahan sensor api sebagai fitur keamanan dan konektivitas internet dikembangkan oleh (13). Kepentingan informasi keadaan kapasitas tempat sampah untuk manajemen pengumpulan limbah ditambah dengan sensor kelembaban dilaporkan oleh (14). Penggunaan sensor infra merah pasif diterangkan salah satunya oleh (15), hal yang digunakan untuk menarik pengguna antara lain adalah dengan memakai rekaman suara. Pelaporan status tempat sampah melalui SMS dibahas dalam artikel oleh (16). Pelaporan melalui surel dibahas oleh (17). Konektivitas IoT untuk tempat sampah pintar dengan menggunakan platform ESP32 dilaporkan oleh (18). Keakuratan ketinggian isi dari tempat sampah ditambahkan keakuratannya dengan tambahan logika fuzzy sebagaimana yang dicoba oleh (19). Hal menarik yang disampaikan oleh (20) adalah penambahan perlakuan penambahan material yang berfungsi sebagai anti mikroba NaDCC pada sampah padat yang berada di ruang pelayanan kesehatan selama belum diangkut ke sarana pengolahan limbah berikutnya.

Tempat sampah pintar dapat menjadi salah satu solusi alat penunjang untuk pencegahan infeksi nosokomial di lingkungan layanan kesehatan. Tempat sampah ini berfungsi sebagai pencegah kontaminasi silang karena kontak fisik, melalui fitur buka tutup otomatis. Sistem ini juga membantu mempermudah manajemen pengambilan limbah oleh pihak sanitasi pelayanan kesehatan, melalui pelaporan status kapasitas tempat sampah. Secara tidak langsung, juga mengajak agar pihak non pasien dan non tenaga kesehatan yang berada di lingkungan pelayanan kesehatan semakin berdisiplin dalam membuang sampah karena penggunaannya yang unik dan memberikan pengalaman baru, khususnya di kalangan anak-anak.

Artikel ini akan membahas tentang pembuatan tempat sampah pintar sebagai penunjang pencegahan infeksi nosokomial. Bagian selanjutnya akan menjelaskan tentang detail sistem yang digunakan dan ditutup dengan laporan kinerja dari sistem yang dibuat. 


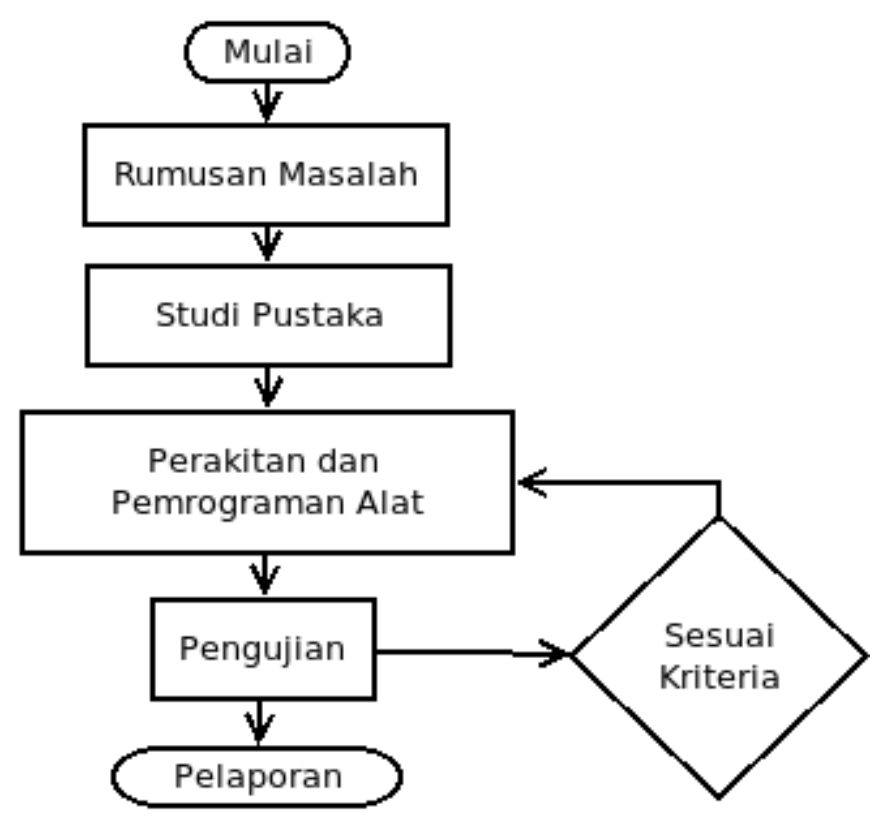

Gambar 1 Skema metode penelitian

\section{METODE PENELITIAN}

Penelitian ini merupakan penelitian kuantitatif eksperimen. Alat rancang berdasarkan kebutuhan masalah, kemudian dirakit dan diprogram. Pengambilan data primer dilakukan dengan pengujian langsung fungsional inti alat yang memanfaatkan dummy sampah, karena sifat berbahaya dari penggunaan sampah medis yang asli. Di samping itu, sifat proteksi dan perlindungan terhadap kontaminasi sangat tergantung pada pelapisan sistem yang saat sistem dibuat belum dibuat. Teknik pengambilan sampel menggunakan purposive sampling (21) karena non probabilistik dengan pemilihan yang sesuai kebutuhan peneliti. Skema penelitian ini dapat dilihat pada gambar 1. Rumusan masalah akan menghasilkan tujuan dari penelitian dan batasanbatasan yang akan diselesaikan dari kegiatan penelitian. Selanjutnya studi pustaka dilakukan untuk mengumpulkan solusi yang sudah dibuat dan untuk mendapatkan inspirasi solusi yang baru. Alat dirakit dan diprogram, kemudian diuji dan diambil datanya. Pengambilan data menggunakan metode data paling stabil, karena toleransi data cukup besar dan tidak berdampak besar pada aplikasi. Apabila sudah memenuhi kriteria yang ditentukan pada rumusan masalah, maka penelitian dilaporkan dan dinyatakan selesai sampai batas ini. Hasil dari pengukuran tersebut akan diolah untuk dianalisa lebih lanjut menggunakan metode kuantitatif deskriptif. 


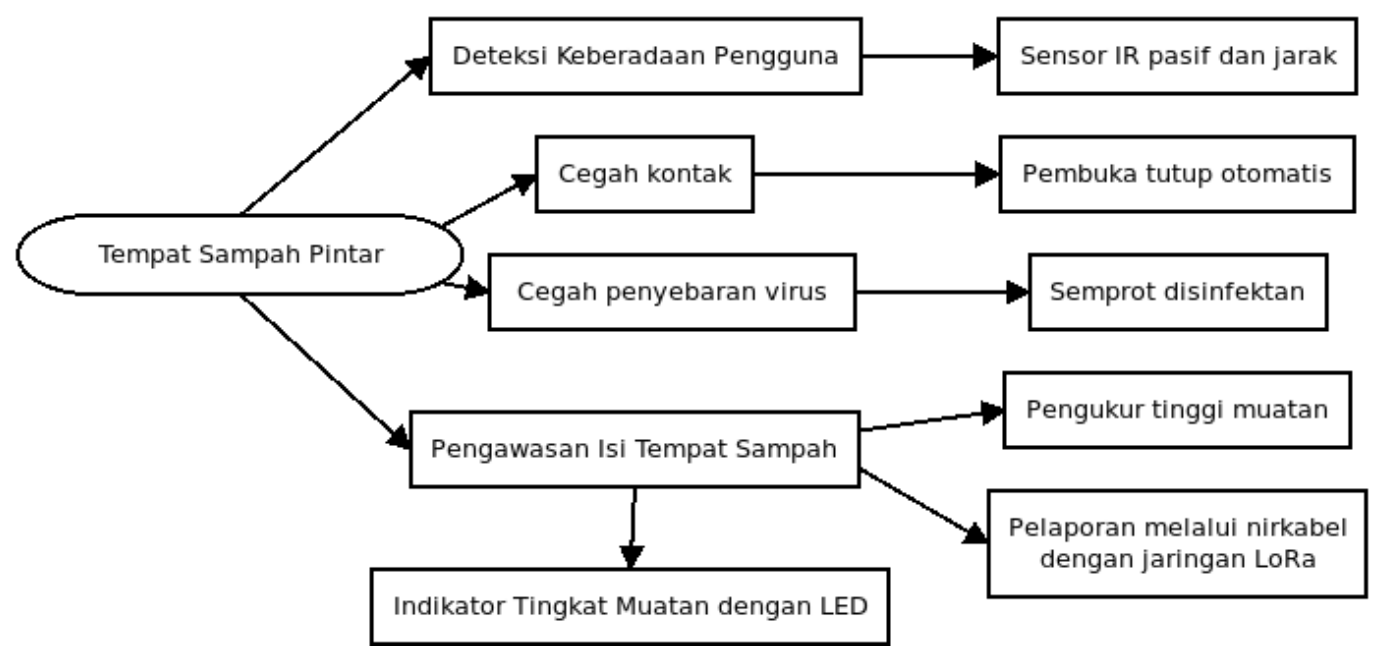

Gambar 2 Rumusan masalah dan solusi yang diajukan

Permasalahan yang ingin diselesaikan adalah perakitan tempat sampah pintar. Tempat sampah pintar harus bisa mendeteksi keberadaan pengguna dan merespon berdasarkan keadaan ini. Detektor keberadaan pengguna harus dimiliki, dan ada sistem mikrokontroler yang dapat merespon keadaan yang ada. Demi meminimalkan kontaminasi kontak, maka tempat sampah bisa membuka dan menutup secara otomatis. Sampah yang dimasukkan harus dikondisikan agar meminimalkan tumbuhnya bakteri dan virus, sehingga diperlukan penyemprotan desinfektan. Tempat sampah harus bisa mengetahui kondisi kapasitas sampah yang masih bisa ditampung, oleh karena itu digunakan sensor ketinggian non kontak untuk mengukur tinggi permukaan sampah dalam kontainer. Bila tempat sampah penuh, harus ada indikator yang menandakan kondisi isi dari tempat sampah. Digunakanlah indikator LED dan komunikasi nirkabel yang akan memberi peringatan pada pihak yang berkepentingan. Sistem akan lebih memudahkan apabila memiliki sumber daya energi sendiri dan memiliki waktu hidup yang cukup lama, maka prioritas pada penggunaan daya yang rendah menjadi penting. Pesan peringatan yang dikirimkan secara ukuran isi pesan tidaklah besar dan intervalnya sangat jarang. Disamping itu diasumsikan infrastruktur komunikasi tidak selalu dapat diandalkan, dan sistem pun jangan sampai menyita sumber daya komunikasi nirkabel terlalu besar. Hubungan antara rumusan masalah dan bagianbagian masalah serta solusinya ditampilkan pada gambar 2 . 


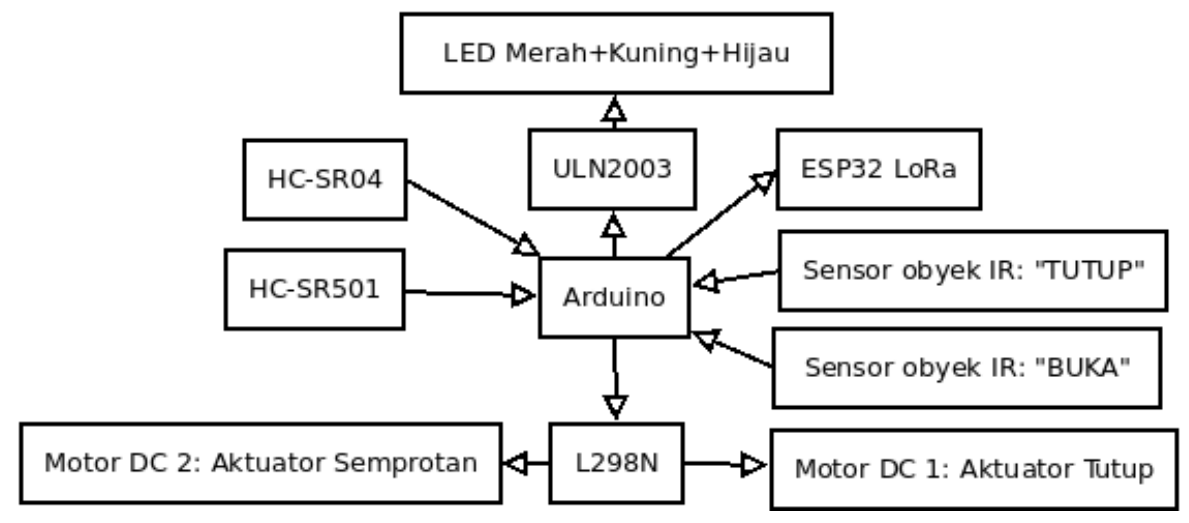

Gambar 3 Skema sistem tempat sampah pintar

Sistem terdiri dari platform Arduino sebagai pengendalinya, yang akan mengendalikan motor DC yang akan diatur layaknya servo untuk penggerak tutup. Hal ini dipilih karena pengendalian dengan motor servo memiliki keadaan yang tertentu yang bisa dipastikan posisinya. Motor DC digunakan untuk mengendalikan penyemprotan. Penggerakan motor DC memerlukan driver atau relay yang sesuai dengan kebutuhan arus dari motor DC dan mengisolasi dari mikrokontroler. Motor DC hanya bergerak ke satu arah sesuai dengan polaritas yang diberikan. Oleh karena itu, dibuatlah mekanisme dalam bentuk susunan gerigi yang akan menekan nosel aerosol secara periodik. Motor cukup diaktifkan dengan kurun waktu tertentu untuk memastikan nosel telah tertekan. Sensor PIR dengan tipe HC-SR501 difungsikan sebagai pendeteksi keberadaan manusia. Sensor ini memiliki kelebihan tidak terlalu sensitif terhadap pergerakan selain makhluk hidup. Selanjutnya digunakan sensor ultrasonik HC-SR04 untuk membaca tinggi isi sampah dibaca oleh Arduino karena sifatnya yang non kontak dan relatif tidak bereaksi dengan aerosol. 3 unit LED berdaya total sekitar 3 watt dihubungkan sebagai indikator melalui driver ULN2003 untuk menghindari pembebanan pada kaki keluaran mikrokontroler. Pada bagian komunikasi, secara serial dihubungkan dengan platform ESP yang dilengkapi dengan LoRaWAN pada frekuensi $915 \mathrm{MHz}$ untuk konektivitas siaran data. Komunikasi data dengan LoRaWAN mengonsumsi daya yang kecil, bersifat pasif dalam menjaga jalur komunikasi dan dapat mencapai jangkauan lebih dari ratusan meter dalam ruangan. Hal ini sangat ideal untuk skema komunikasi dengan kebutuhan pengabaran informasi dengan frekuensi maksimal 1 (satu) kali sehari. Skema sistem ini diperlihatkan pada 
gambar 3. Sistem disuplai dengan sumber listrik DC berupa baterai $5 \mathrm{~V}$ dengan kapasitas 5000mAh dan suplai arus maksimum 2,5A.

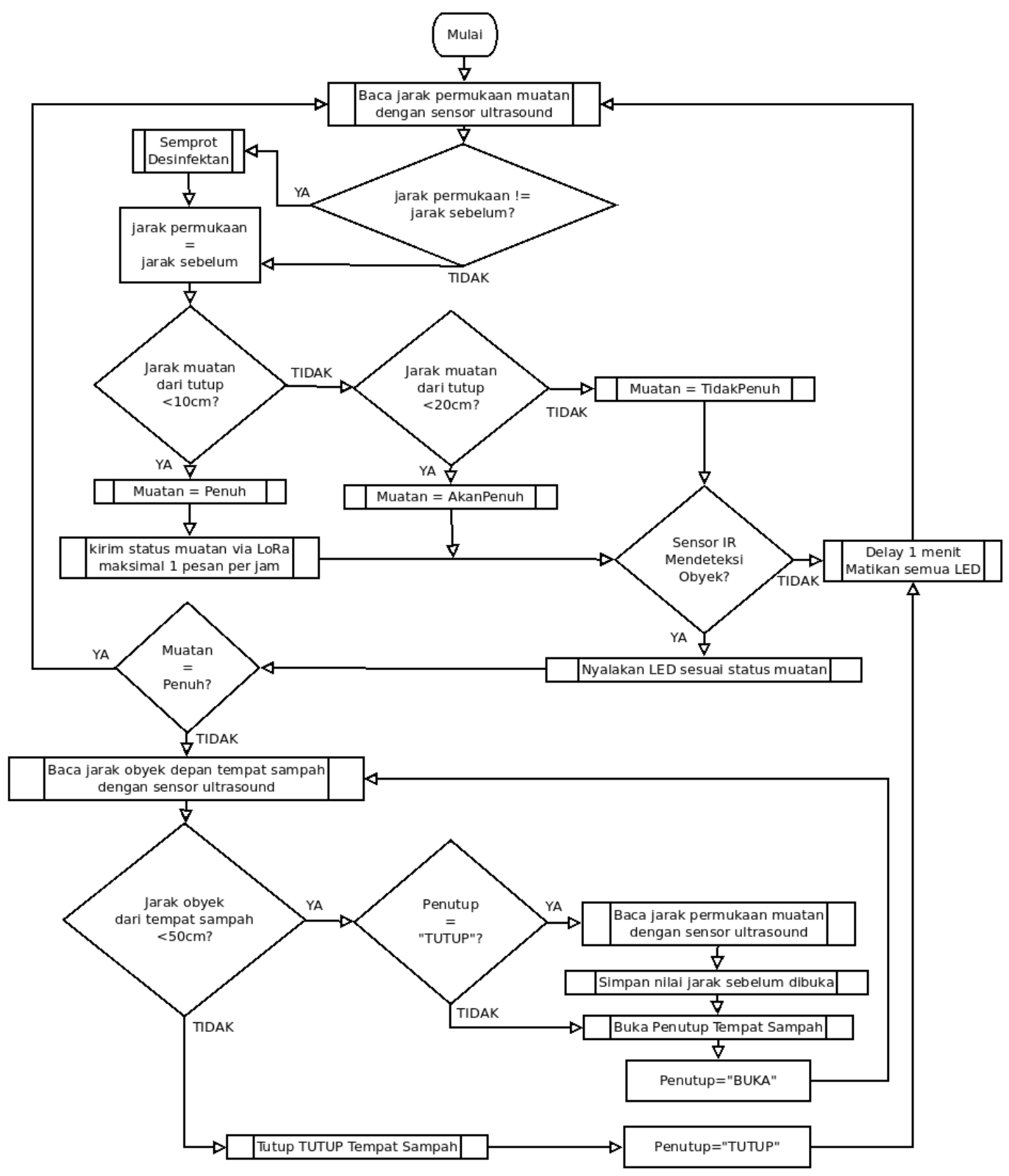

Gambar 4 Diagram alur program sistem tempat sampah pintar

Skema alur program untuk tempat sampah ini ditunjukkan pada gambar 4. Ketika alat diaktifkan, pertama kali yang dilakukan adalah memeriksa level ketinggian volum sampah yang dideteksi oleh sensor ultrasonik. Hasil kalibrasi isi muatan disimpan sebagai batas menengah yang menandakan tempat sampah hampir penuh yaitu sekitar jarak $20 \mathrm{~cm}$ dari sensor ultrasonik, dan batas atas atau sekitar $10 \mathrm{~cm}$ dari sensor sebagai tanda tempat sampah telah penuh. LED akan dinyalakan yang bersesuaian dengan 
kondisi kapasitas tempat sampah, yaitu warna merah untuk indikator tempat sampah telah penuh, warna kuning untuk menandakan bahwa tempat sampah hampir penuh dan warna hijau apabila selain kedua kondisi tersebut. Dalam status selain merah, sistem akan menunggu keluaran sensor PIR yang bersifat active high bila mendeteksi adanya keberadaan orang. Apabila kondisi sensor PIR terpicu, maka sensor ultrasonik pengukur jarak akan diaktifkan untuk mengukur jarak obyek yang memicu sensor PIR. LED akan dinyalakan apabila sensor PIR aktif. Apabila jarak obyek yang terukur oleh sensor ultrasonik kurang dari $50 \mathrm{~cm}$, motor DC akan dinyalakan. Motor akan berhenti apabila sensor IR jarak dekat pada posisi "BUKA" aktif. Apabila jarak obyek yang terukur sensor ultrasonik lebih dari $50 \mathrm{~cm}$ maka motor DC akan diputar berlawanan arah sampai sensor IR jarak dekat pada posisi “TUTUP” aktif. Sistem akan mengukur ketinggian volum tempat sampah. Apabila ada pertambahan ketinggian, maka motor DC akan diputar untuk menekan selama 1 detik untuk menekan botol desinfektan dan kemudian dinyalakan 1 detik arah sebaliknya. Harapannya seluruh permukaan baru akan terlapisi oleh cairan desinfektan. Selanjutnya sistem akan menetapkan statusnya antara hijau, kuning atau merah dan mengulangi proses di atas.

\section{HASIL DAN PEMBAHASAN}

Purwarupa tempat sampah yang telah dirancang disusun sebagaimana yang tampak pada gambar 5. Tempat sampah memiliki bukaan atas yang dibuka oleh motor DC dari ujung tutup. Aksi buka dan tutup tempat sampah oleh motor DC memperhatikan pembacaan sensor pendeteksi infra merah yang aktif apabila terdapat halangan di depan sensor berjarak sekitar 1-3 cm. Terdapat sensor infra merah pasif pendeteksi gerakan dan sensor ultrasonik untuk mendeteksi jarak obyek penyebab gerakan. Kedua sensor ini berada dalam selubung yang hanya mendeteksi jangkauan tertentu. Pada bagian samping dipasang penyemprotan disinfektan yang mengarah ke bagian dalam wadah tempat sampah. Disinfektan yang digunakan adalah tipe disinfektan cair dalam tabung aerosol yang pengaplikasiannya dengan menekan nosel pada bagian atas. Aktuator penekan nosel memanfaatkan mekanisme motor mekanik dari alat penyemprot parfum otomatis. 


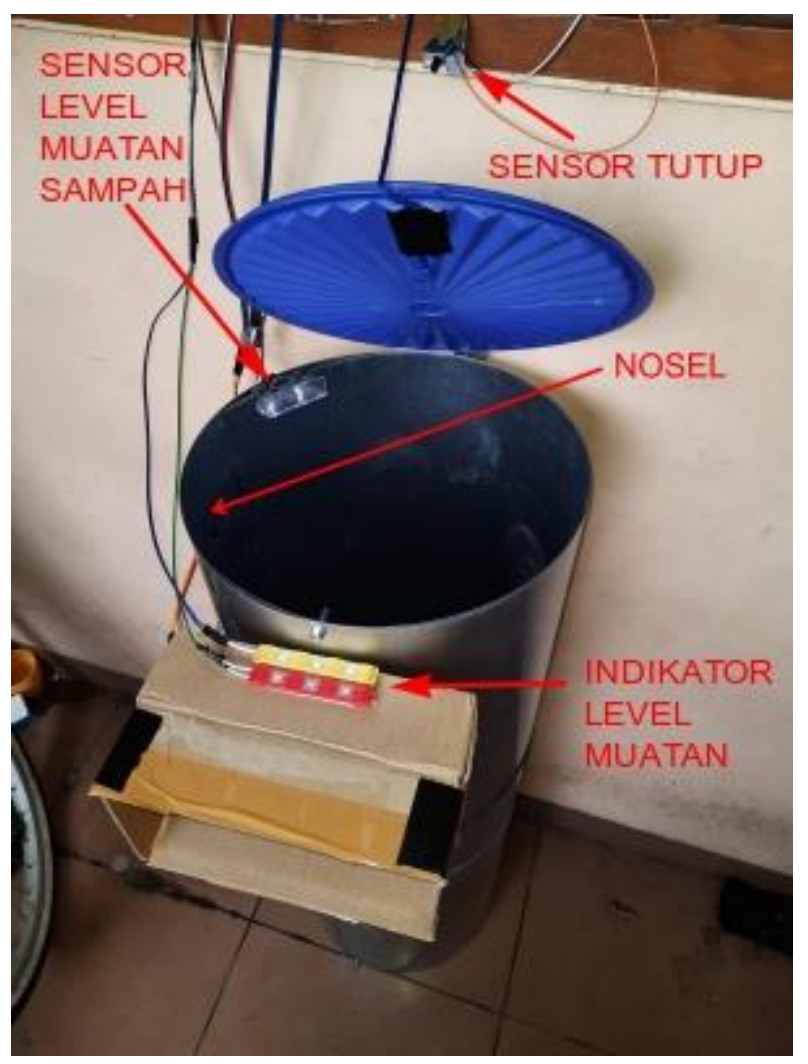

Gambar 5 Susunan sistem tempat sampah pintar

Aktuasi buka tutup ditetapkan untuk mengikuti mekanisme servo berdasarkan status keadaan tutup wadah. Apabila status "TUTUP" ditetapkan dan ada yang membuka tutup, maka sistem secara otomatis akan berusaha untuk melakukan aksi menutup. Pembukaan tutup wadah dilakukan menggunakan tali yang menarik ujung depan tutup wadah sampai terdeteksi sensor infra merah aktif bahwa wadah telah berada pada posisi terbuka. Tutup wadah ditutup dengan mengendurkan tali sampai tutup wadah terdeteksi sensor telah berada pada posisi menutup. Waktu yang diperlukan untuk membuka atau menutup wadah rata-rata sekitar 5 detik.

Mekanisme penekan tabung disinfektan tipe aerosol memanfaatkan mekanisme penekan tabung parfum. Ukuran tabung disinfektan dipilih yang pas dengan ukuran wadah tabung parfum yang ada. Motor DC penggerak mekanisme penekanan disuplai melalui driver L293N, dengan menggerakkan motor ke arah tekan selama 1 detik kemudian dilanjutkan dengan menggerakkan motor ke arah posisi awal selama 1 detik. Meskipun ukuran tabung aerosol disinfektan sama dengan ukuran tabung aerosol parfum, terkadang aksi penekanan tidak berhasil menyemprotkan disinfektan 
meskipun sangat jarang terjadi. Kemungkinan terjadi variasi kekuatan dalam aksi menekan nosel tabung disinfektan aerosol. Sekitar 5\% kegagalan penyemprotan terjadi selama pengujian.

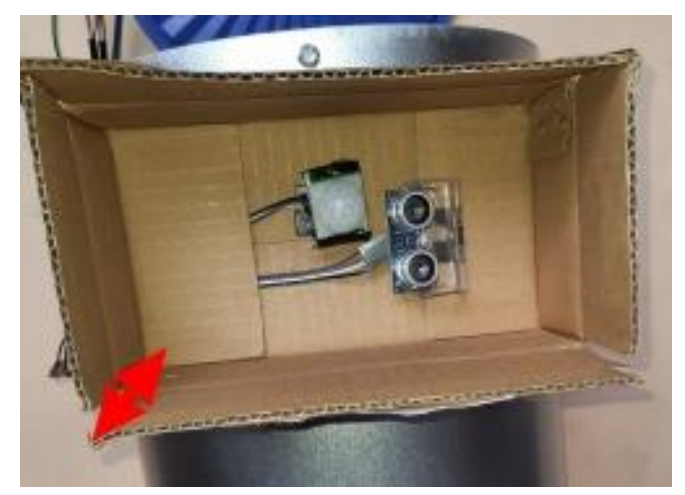

Gambar 6 Profil selubung sensor infra merah pasif tempat sampah pintar

Posisi ideal untuk menempatkan arah semprotan disinfektan adalah vertikal mengarah ke permukaan wadah sampah. Hanya saja tabung disinfektan aerosol tidak dapat bekerja dengan baik pada orientasi nosel vertikal ini. Oleh karena itu, posisi keluaran nosel berada pada bagian atas wadah dan orientasi nosel adalah horizontal. Diharapkan sebagian besar permukaan sampah dan sebagian tutup wadah dapat tersemprot dengan cairan disinfektan. Posisi lubang penyemprotan (nosel) ini telah diperlihatkan pada gambar 5 .

Pendeteksian pengguna oleh sensor infra merah pasif didesain hanya pada sudut sempit dengan jarak kurang dari 3 meter. Selubung digunakan sedemikian sehingga pada jarak 3 meter, jangkauan deteksi ke kiri dan kanannya kurang lebih 1,5 m dengan profil selubung ditunjukkan pada gambar 6. Data hasil deteksi ditunjukkan pada gambar 7. Posisi sensor infra merah pasif berada pada bagian tengah dengan profil selubung berukuran horizontal $20 \mathrm{~cm}$, vertikal $12 \mathrm{~cm}$ dan kedalaman selubung sekitar $12 \mathrm{~cm}$. Tampak dari gambar, selubung ini menghasilkan profil deteksi ke samping sesuai dengan hasil perancangan. Apabila sensor infra merah pasif mendeteksi adanya pergerakan, maka sensor ultrasonik pengukur jarak diaktifkan untuk mendeteksi secara aktif posisi pengguna wadah sampah. Apabila terdeteksi pergerakan dan kapasitas wadah penuh maka led merah akan menyala Apabila posisi pengguna berada pada jarak kurang dari $50 \mathrm{~cm}$ dan wadah sampah tidak penuh maka wadah sampah akan 
melakukan aksi membuka tutup wadah. Apabila pengguna menjauh lebih dari $50 \mathrm{~cm}$ maka wadah sampah akan melakukan aksi menutup.

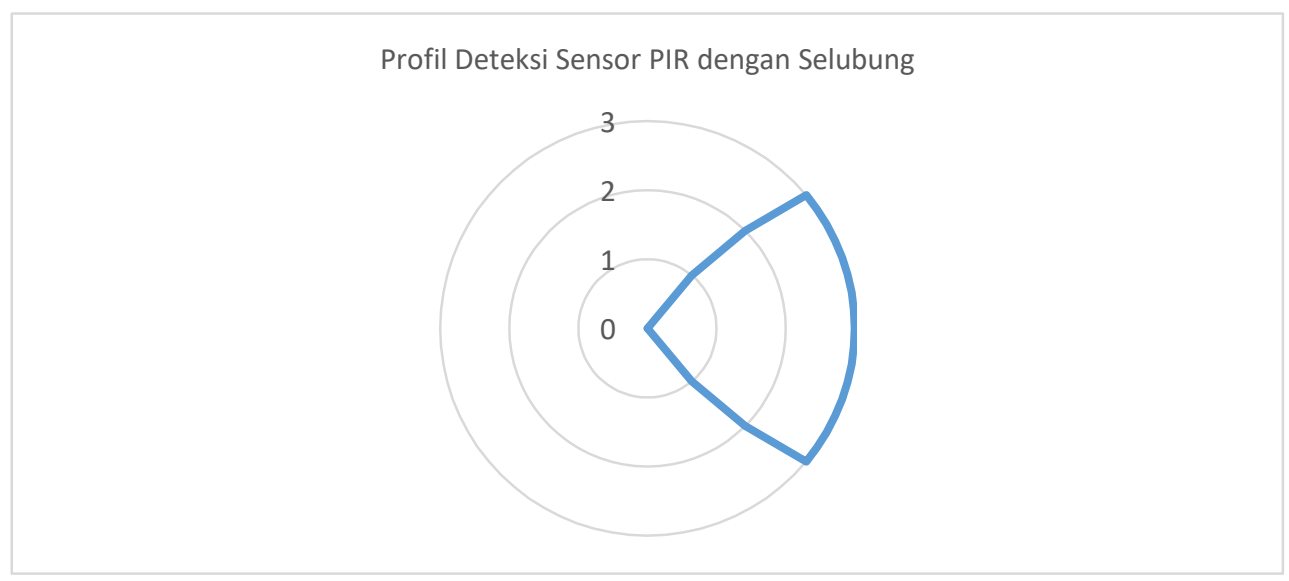

Gambar 7 Profil deteksi sensor infra merah pasif tempat sampah pintar

Selanjutnya sensor ultrasonik yang berada di dalam wadah sampah akan mendeteksi tinggi muatan wadah setelah aksi penutupan. Apabila ada penambahan ketinggian muatan, maka disinfektan akan disemprotkan pada permukaan sampah. Data kalibrasi sensor ultrasonik yang dipergunakan pada penelitian ini diberikan pada gambar 8. Secara umum data sensor cukup akurat dan dipilih rentang pengukuran yang berada pada rata-rata galat kurang dari $10 \%$. Bentuk dan rupa sampah yang dideteksi yang acak dan tidak mulus sebagai penyebab perbedaan data ketinggian yang dideteksi antar pengukuran.

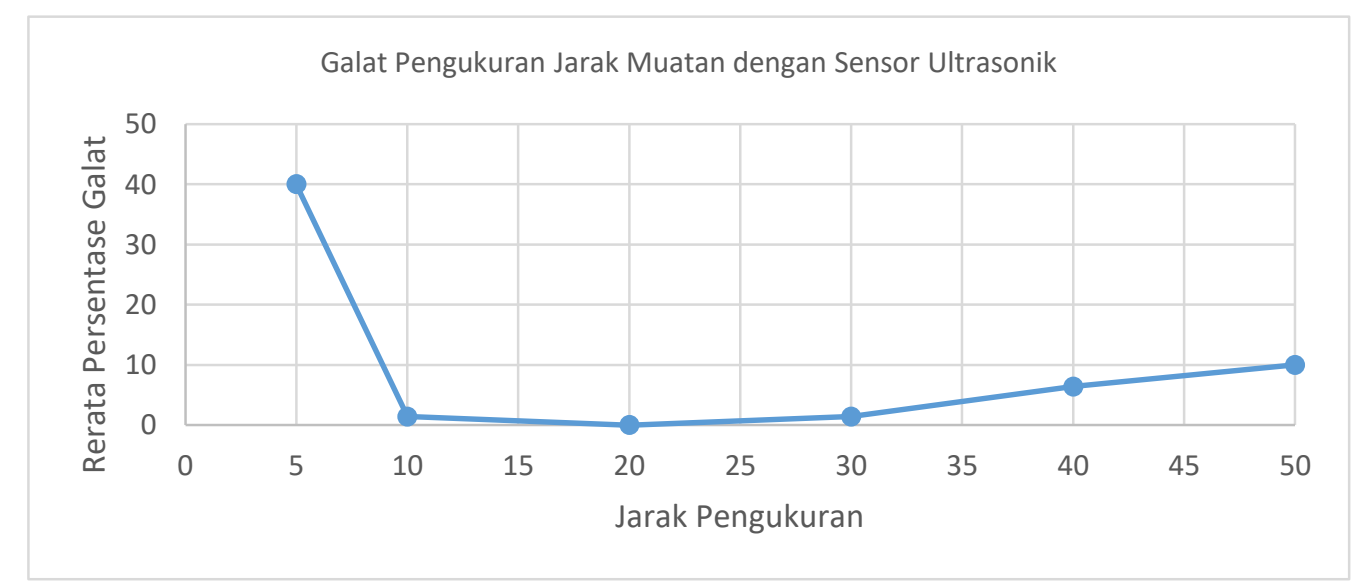

Gambar 8 Kalibrasi pengukuran tinggi muatan tempat sampah pintar 
Manajemen penanganan limbah yang baik akan mengosongkan wadah sampah sebelum sampah memenuhi wadah sehingga tidak terjadi penumpukan. Pelaporan keadaan kapasitas wadah sampah dilaporkan melalui sistem komunikasi LoRa yang diujikan pada gedung kuliah Poltekkes Kemenkes Jakarta II. 2 skema yang diuji adalah wadah sampah berada di dalam gedung dan di luar atau lingkungan terbuka. Sistem komunikasi mengirimkan data dengan kode khusus sehingga bisa diketahui identitas pengirim. Sistem penerima komunikasi selalu berada di dalam ruangan, sedangkan sistem pengirim komunikasi menempel pada setiap wadah sampah. Kriteria keberhasilan pengujian komunikasi terjauh adalah apabila pesan komunikasi masih dapat diterima secara utuh. Diperoleh data adalah maksimal 15 meter untuk komunikasi di dalam gedung dan sekitar minimal 65 meter untuk komunikasi di luar gedung. Posisi pengujian ditunjukkan pada gambar 9 berikut. Uji dalam gedung adalah antara lantai 1 dari gedung yang berbeda dengan gedung yang bersebelahan. Uji luar gedung adalah antara lantai 1 gedung dengan jalan di depan gedung. Posisi stasiun penerima selalu berada di dalam ruangan.

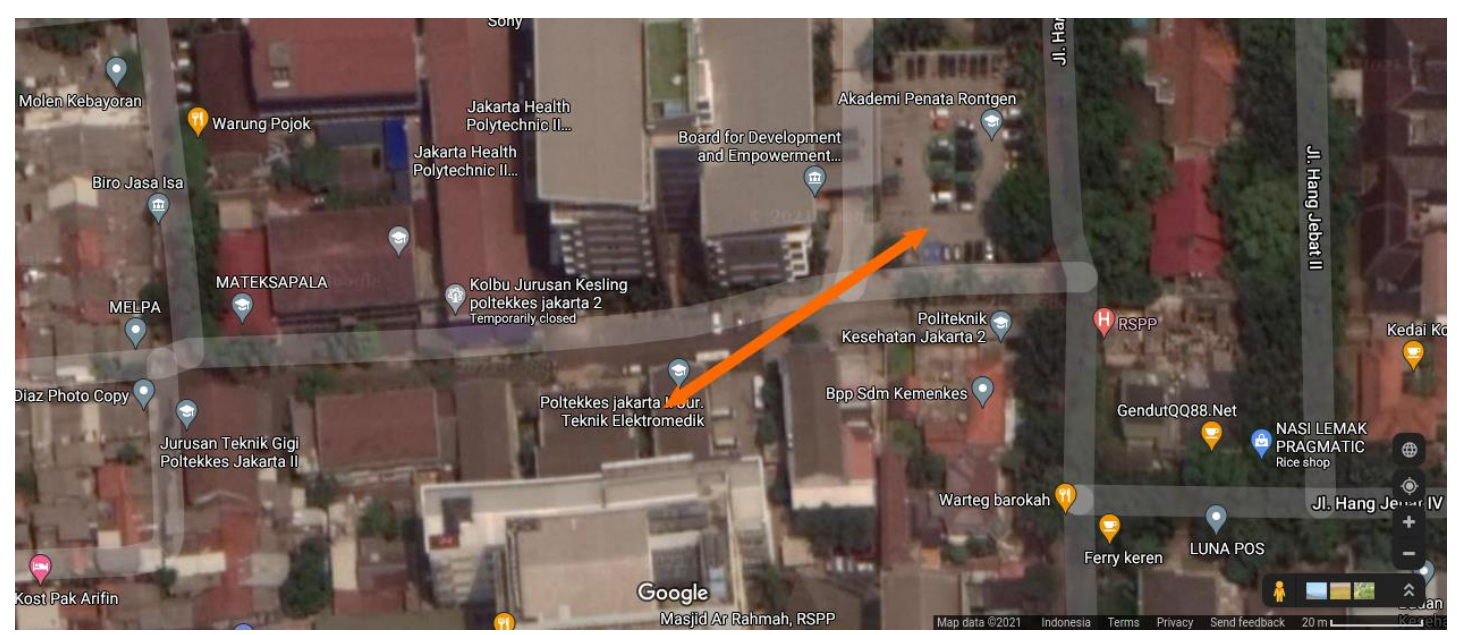

Gambar 10 Tampak atas posisi pengujian jarak komunikasi luar ruangan

\section{SIMPULAN}

Fungsi alat untuk menjadi tempat sampah pintar yang bisa secara otomatis membuka ketika ada pengguna, dan menyemprotkan desinfektan ketika dideteksi ada pertambahan ketinggian isi dari tempat sampah. Indikator tempat sampah juga berfungsi dengan baik, termasuk tidak membuka tutup tempat sampah ketika sudah berada pada level merah atau $90 \%$ dari kapasitas maksimal. 
Penelitian selanjutnya dapat diteruskan pada menyusun sistem yang dapat tahan ketika disinfeksi atau terpapar dengan cairan kimia keras yang digunakan untuk membersihkan tempat sampah. Alat ini juga perlu dikaji ulang apabila menginginkan konsumsi daya yang lebih kecil. Sistem pelaporan masih harus disesuaikan dengan ritme kerja unit pembersihan layanan kesehatan secara riil sehingga dapat memenuhi kebutuhan.

\section{DAFTAR PUSTAKA}

1. Kasumayanti E. Faktor-faktor yang berhubungan dengan infeksi nosokomial pada pengelola limbah medis padat (cleaning service) di RSUD Bangkinang tahun 2016. Jurnal Ners. 2017 Oct 26;1(2).

2. Khan HA, Baig FK, Mehboob R. Nosocomial infections: Epidemiology, prevention, control and surveillance. Asian Pacific Journal of Tropical Biomedicine. 2017 May 1;7(5):478-82.

3. Puspasari Y. Hubungan Pengetahuan, Sikap Dengan Praktik Perawat Dalam Pencegahan Infeksi Nosokomial Diruang Rawat Inap Rumah Sakit Islam Kendal. FIKkeS. 2015;8(1).

4. Hati Y. Hubungan Pengetahuan Dengan Tindakan Perawat Tentang Pencegahan Infeksi Nosokomial Di Rumah Sakit Umum Haji Abdul Manan Simatupang Tahun 2016. Jurnal STIKes RS. Haji Medan. 2016;9(2).

5. Syahrir S, Tirmanidhana F, Raodhah S, Bujawati E. Analisis Pelaksanaan Pencegahan dan Pengendalian Infeksi Nosokomial Di ICU RSUD Labuang Baji Makassar. HIGIENE: Jurnal Kesehatan Lingkungan. 2018 Aug 27;4(2):67-73.

6. Abubakar N. Pengetahuan Dan Sikap Keluarga Pasien Rawat Inap Rumah Sakit Haji Surabaya Terhadap Pencegahan Infeksi Nosokomial. Jurnal Manajemen Kesehatan Yayasan RS. Dr. Soetomo. 2017 Oct 28;3(2):178-90.

7. Lelonowati D, Koeswo M, Rochmad K. Faktor Penyebab Kurangnya Kinerja Surveilans Infeksi Nosokomial di RSUD Dr. Iskak Tulungagung. Jurnal Kedokteran Brawijaya. 2015 Aug 6;28(2):186-94.

8. Fakoorziba MR, Eghbal F, Hassanzadeh J, Moemenbellah-Fard MD. Cockroaches (Periplaneta americana and Blattella germanica) as potential vectors of the pathogenic bacteria found in nosocomial infections. Annals of Tropical Medicine \& Parasitology. 2010 Sep 1;104(6):521-8.

9. Hendryani A, Azhim H. Design of Led Base Bell's Palsy Therapy Device Using Microcontroller ATmega 8535. Sanitas. 2019 Oct 31;10(1):14-25.

10. Usman A, Marwazi H, Alam S. Temperature And Humidity Test Of The Telemetry Tool Modeling In Baby Incubator. Sanitas. 2018 Jun 1;9(1):16-23.

11. Handayani IN, Mamurotun M. Indoor Dust Exposure Detection System For Air Purifier Controller Based Arduino And LabVIEW. Sanitas. 2019 Oct 31;10(1):46-58.

12. Fatmawati K, Sabna E, Irawan Y. Rancang Bangun Tempat Sampah Pintar Menggunakan Sensor Jarak Berbasis Mikrokontroler Arduino. Riau Journal Of Computer Science. 2020 Sep 20;6(2):124-34. 
13. Yahya R, Alfi I. PURWARUPA KOTAK SAMPAH PINTAR BERBASIS IoT (Internet Of Thing (Doctoral dissertation, University of Technology Yogyakarta).

14. Asriani A, Aprilia ER. TeMP (Tempat Sampah Pintar): Alat Monitoring dan Pendeteksi Kelembaban Sampah Berbasis Mikrokontroller. Jurnal Teknologi Elekterika. 2019 May 30;16(1):39-42.

15. Hidayat CR, Syahrani FD. Perancangan Sistem Kontrol Arduino Pada Tempat Sampah Menggunakan Sensor PIR dan Sensor Ultrasonik. Jurnal VOI (Voice of Informatics). 2017 Jan 11;6(1).

16. Samann FE. The design and implementation of smart trash bin. Academic Journal of Nawroz University. 2017 Aug 30;6(3):141-8.

17. Widodo YB, Sutabri T, Faturahman L. Tempat sampah pintar dengan notifikasi berbasis iot. Jurnal Teknologi Informatika Dan Komputer. 2019 Oct 1;5(2):507.

18. Muliadi M, Imran A, Rasul M. Pengembangan tempat sampah pintar menggunakan ESP32. Jurnal Media Elektrik. 2020 Mar 9;17(2):73-9.

19. Furqan M, Kurniawan R, Rambe IG. Tempat Sampah Pintar Dengan Logika Fuzzy Berbasis NodeMCU. Indonesian Journal of Computer Science. 2020 Apr 10;9(1):11-21.

20. Motta O, Zarrella I, Cucciniello R, Capunzo M, De Caro F. A new strategy to control the proliferation of microorganisms in solid hospital waste and the diffusion of nosocomial infections. Infez Med. 2018 Sep 1;26(3):210-5.

21. Etikan I, Musa SA, Alkassim RS. Comparison of convenience sampling and purposive sampling. American journal of theoretical and applied statistics. 2016 Jan 5;5(1):1-4. 